\title{
Immunmediált glomerularis károsodások
}

\author{
Pap Domonkos dr. ${ }^{1,2}$. Vannay Ádám dr. ${ }^{1,2}$ - Szabó J. Attila dr. ${ }^{1,2}$ \\ ${ }^{1}$ MTA-SE Gyermekgyógyászati és Nephrologiai Kutatócsoport, Budapest \\ ${ }^{2}$ Semmelweis Egyetem, Általános Orvostudományi Kar, I. Gyermekgyógyászati Klinika, Budapest
}

\begin{abstract}
A vese filtrációs alapegységei a glomerulusok, melyek passzív hemodinamikai feladatukon túl komplex szabályozási mechanizmusokban is részt vesznek. Ezek közül fontosak az immunmediált folyamatok, amelyek a glomerularis homeostasis élettani biztosításán túl lokális szövetkárosító mechanizmusokat is elindíthatnak. Az immunológiai eredetú krónikus glomerularis betegségek gyakori okai a végstádiumú vesebetegség kialakulásának. Az immunrendszer kétélü kardként részt vesz a vese fiziológiás állapotának fenntartásában, de emellett meghatározó szerepe van a glomerularis károsodások kiváltásában. A nem megfelelően szabályozott, túlzott mértékü immunválasz felelős a glomerulonephritisek jelentős részéért, mely folyamat során károsodhat a glomerulusokat alkotó valamennyi strukturális és sejtes elem, beleértve a glomerularis bazálmembránt, a mesangialis és kapilláris-endothelsejteket, a podocytákat, valamint a parietalis epithelsejtréteget. Közleményünkben az egyes glomerularis komponenseknek, valamint a természetes és adaptív immunrendszernek a glomeruluskárosodásban betöltött szerepét foglaljuk össze.
\end{abstract}

Orv Hetil. 2020; 161(24): 993-1001.

Kulcsszavak: nephrologia, glomerulonephritis, immunválasz

\section{The immunological background of glomerular injuries}

The basic structural units of the renal filtration are the glomeruli, which, in addition to their passive hemodynamic function, also participate in complex immune-mediated mechanisms. The immune system as a double-edged sword maintains the physiological homeostasis of the glomeruli, but also plays a crucial role in the induction of glomerular damage. The immune-mediated chronic glomerular injures are the most common cause of end-stage renal diseases. The unregulated and overactive immune response can damage both the structural and the cellular components of the glomeruli, including the glomerular basal membrane, mesangial and capillary endothelial cells, podocytes, and parietal epithelium. The manuscript summarizes the role of the glomerular components and the natural and adaptive immune response in the pathomechanism of glomerular diseases.

Keywords: nephrology, glomerulonephritis, immune system

Pap D, Vannay Á, Szabó JA. [The immunological background of glomerular injuries]. Orv Hetil. 2020; 161(24): 993-1001.

(Beérkezett: 2020. február 7.; elfogadva: 2020. március 7.)

\section{Rövidítések}

aHUS = atípusos haemolyticus uraemiás szindróma; ANCA = (antineutrophil cytoplasmic antibodies) a neutrophil granulocyták citoplazmájában lévő különféle enzimek elleni antitestek gyújtőneve; CCL5 = (chemokine [C-C motif] ligand 5) chemokinligand $-5 ; \mathrm{CD}=$ (cluster of differentiation) differenciációs klaszter; $\mathrm{CTGF}=$ (connective tissue growth factor $)$ kötőszöveti növekedési faktor; DNS = dezoxiribonukleinsav; $\mathrm{GBM}=$ (glomerular basement membrane $)$ glomerularis bazálmembrán; FEKUTSTRAT = Felsőoktatás- és Kutatásstratégia;
HLAII = humán leukocytaantigén-II; IFN $\gamma=$ interferon-gamma; Ig = immunglobulin; IL = interleukin; $\mathrm{Ki}-67$ = proliferációs index; $\mathrm{KVB}=$ krónikus vesebetegség; $\mathrm{M}=$ macrophag; $\mathrm{MAC}=($ membrane attack complex $)$ membránkárosító komplex; MASP $=($ MBL-associated serine protease $)$ MBL asszociálta szerin-proteáz; MBL $=$ (mannose-binding lectin $)$ mannózkötő lektin; MCPl = monocyte chemoattractant protein-1; MHCII = (major histocompatibility complex II) fó hisztokompatibilitási komplex-II; OTKA = Országos Tudományos Kutatási Alapprogramok; PCNA = (proliferating cell nuclear 
antigen) proliferáló sejtmagantigén; PDGF $=$ (platelet-derived growth factor) vérlemezke-eredetû növekedési faktor; Tc = citotoxikus T-sejt; TGF $\beta=$ (transforming growth factor beta) transzformáló növekedési faktor-béta; Th = helper T-sejt; Thl = 1-es típusú helper T-lymphocyta; Th2 = 2-es típusú helper T-lymphocyta; TLR $=($ Toll-like receptor $)$ Toll-szerú receptor; $\mathrm{TNF} \alpha=$ (tumor necrosis factor alpha) tumornekrózisfaktoralfa; Treg $=$ regulátor T-sejtek; VEGF $=$ (vascular endothelial growth factor) vascularis endothelialis növekedési faktor

A krónikus vesebetegség (KVB) prevalenciája világszinten $8 \%$ és $16 \%$ közé tehető, és gyors ütemben növekszik [1]. Etiológiájától függetlenül a KVB jellemzője a glomerulusok károsodása, melynek mértéke korrelál a vesefunkció beszúkülésével [2]. A glomerulust alkotó endothel-, mesangialis sejtek, podocyták és parietalis epithelsejtek, valamint a bazálmembrán szoros funkcionális kapcsoltságban állnak egymással, ezért ha valamelyikük sérül, az befolyásolja a teljes glomerulus múködését (1. ábra). A glomerularis károsodások - glomerulonephritisek - hátterében jellemzően a természetes és adaptív immunrendszer nem megfelelően szabályozott múködése áll. Mivel a glomerularis komponensek filtrációs tevékenységükből fakadóan folyamatos kapcsolatban vannak az immunrendszer humoralis és sejtes elemeivel, ez fokozza sérülékenységüket a szervezetben zajló immunreakciók során [3]. Az immun-patomechanizmusú glomerulonephritist antitestfüggő és antitestfüggetlen mechanizmusok is szabályozhatják. A humoralis immunválasz következtében kialakuló antitestfüggő glomeruluskáro- sodásért a 2-es típusú helper T-lymphocyták (Th2) által aktivált B-lymphocyták ellenanyag-termelése felelős. A folyamat során a keringésből származó antitestek depozitumokat alkotnak a glomerulusokban, lokális gyulladást indukálva, melynek során aktiválódik a komplementrendszer és a rezidens immunsejtek (macrophagok, granulocyták), megemelkedik a gyulladásoscitokin-termelésük, valamint sejtproliferációval és szöveti átrendeződéssel járó folyamatok indukálódnak. Antitestfüggetlen módon is kialakulhatnak a felsorolt glomeruluskárosodással járó folyamatok. Ezekben az esetekben a cellularis immunválasz aktiválódik, és az l-es típusú helper T-lymphocyta (Thl) sejtek által mediált citotoxikus immunválasz vezet károsodáshoz a glomerulus valamelyik komponensében [4]. A glomerulusok sejtes és strukturális elemei a különböző károsító hatásokra csak korlátozott módon tudnak reagálni, ezért a különböző okok hasonló morfológiai és funkcionális eltérésekhez vezetnek.

\section{A glomerularis komponensek szerepe}

\section{Mesangialis sejtek}

A megnyúlt, szabálytalan alakú mesangialis sejtek és az általuk termelt kollagének, proteoglikánok, valamint fibronektin által alkotott mátrix egyfajta tengelyt alkot a glomerulusban, strukturális támasztékot biztosítva a kapillárishálózatnak. A glomerulus károsodása esetén fokozódik a kapillárisok endothel- és mesangialis sejtjeit elvá-

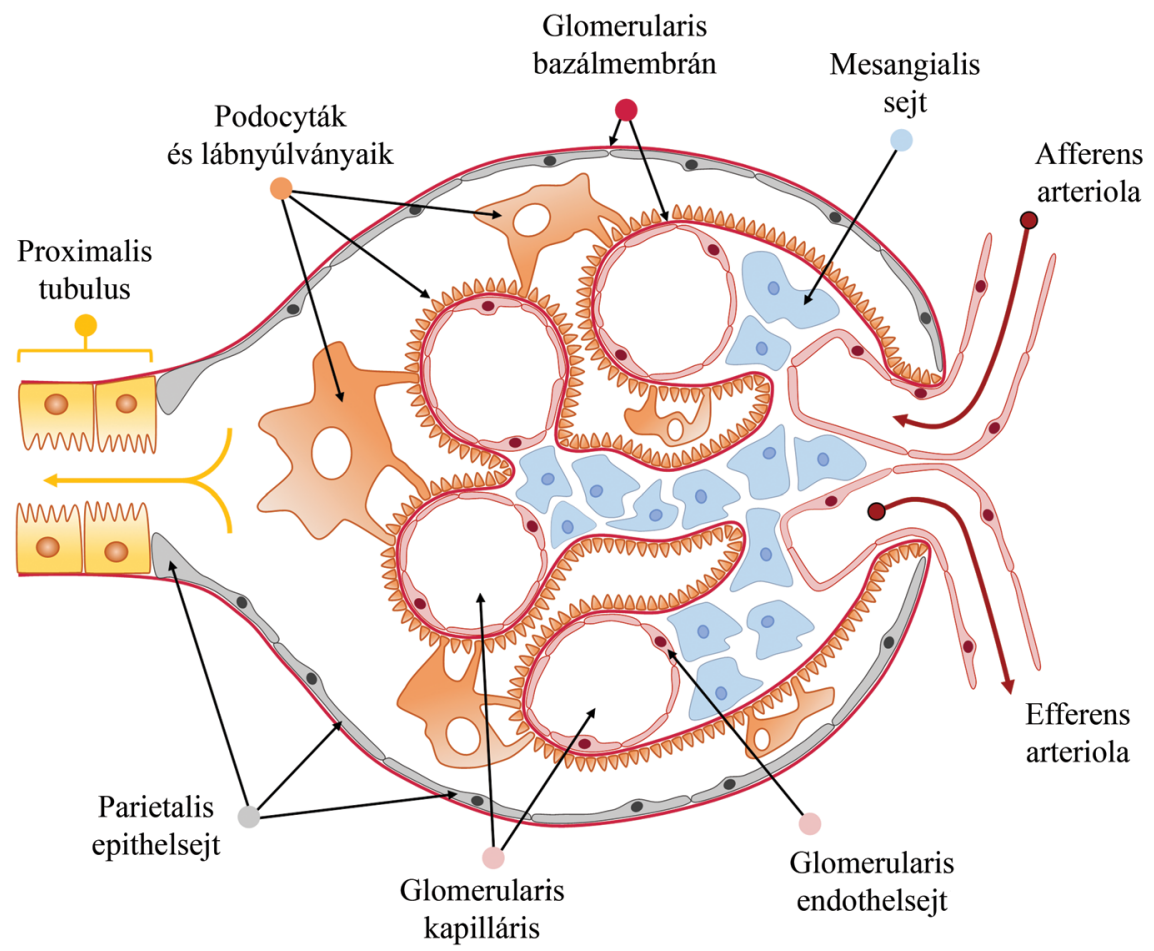

1. ábra

| A glomerulus szerkezeti felépítése (Michal Komorniczak nyomán) 
lasztó glomerularis bazálmembrán permeabilitása, ami lehetővé teszi a különböző immunglobulinoknak és immunkomplexeknek a mesangiumban történő felhalmozódását (például IgA-nephritis). Az immunglobulinaggregátumok hatására fokozódik a lokális interleukin-1 (IL1), IL6, valamint tumornekrózisfaktor-alfa (TNF $\alpha)$ gyulladásos citokinek termelése. Emellett szintén emelkedik a szöveti átépülést szabályozó transzformáló növekedési faktor-béta (TGFß), a vérlemezke-eredetű növekedési faktor-B (PDGFB), valamint a kötőszöveti növekedési faktor (CTGF) expressziója [5]. A mesangialis sejtek proliferációs aktivitása jól korrelál a proliferáló sejtmagantigén (PCNA), valamint a Ki-67 proliferációs markerek pozitivitásával [6]. A gyulladásos citokinek és a növekedési faktorok által aktivált mesangialis sejtek nagy mennyiségben expresszálnak extracellularismátrix-komponenseket (kollagénrostok, proteoglikánok, fibronektin), mely folyamat mesangiumexpanzióhoz, ezáltal pedig a glomerulus filtrációs képességének beszúküléséhez vezet. A mesangialis expanzió jellemző hisztológiai megnyilvánulása az IgA-nephritisnek, valamint a diabeteses nephropathiának [7].

\section{Glomerularis bazálmembrán}

A glomerularis bazálmembrán (GBM) a podocyták és az endothelsejtek által termelt, közöttük húzódó vékony, lemezszerú réteg. A GBM fö alkotóeleme az extracellularismátrix-komponensek mellett a hálószerü struktúrába rendeződő, IV-es típusú kollagén, mely hozzájárul a GBM-re jellemző szelektív permeabilitású glomerularis szúrőfelület kialakításához [8]. Az így létrejövő filtrációs barrier méret- és töltésfüggő módon gátat szab a különböző makromolekulák, antitestek, valamint immunkomplexek vasculaturából vizelettérbe történő átjutásának, hozzájárulva ezzel a glomerulusban történő felhalmozódásukhoz. A GBM-alkotó molekulák emellett magas antigenitással is bírnak az immunrendszer számára. Antiglomerularis bazálmembrán nephritis esetén autoantitestek képződnek a GBM-ben is megtalálható IV-es típusú kollagén $\alpha$-láncának C-terminális ( $\mathrm{NCl}$ ) doménje ellen [9]. A GBM ellen termelődő, jellemzően IgG-izotípusú autoantitestek az immunrendszer komplementkaszkádját aktiválva akut glomerulonephritishez vezetnek. Szintén ezen epitóp ellen termelődő autoantitestek felelősek az Alport-szindrómás betegek egy részében vesetranszplantációt követően kialakuló antiGBM-glomerulonephritisért. A GBM immunkomplexek általi károsítása jellemző még a membranosus glomerulonephritisre, valamint a szisztémás lupus erythematosusra [10]. Etiológiától függetlenül a GBM károsodása során az infiltrálódó immunsejtek által termelt proteolitikus enzimek, valamint a lerakódott immunkomplexek által indukált patológiás folyamatok hozzájárulnak a bazálmembrán szakadozottá válásához, megvastagodásához, ezáltal pedig a csökkenő glomerularis filtrációs rátához.

\section{Glomerularis endothelsejtek}

A glomerularis endothelsejtek folyamatos és direkt kapcsolatban vannak a keringéssel. Jellegzetesen ellaposodott morfológia, valamint filtrációt segítő nagyfokú fenesztráltság jellemzi a sejttípust. Az endothelsejtréteg integritásának fenntartásában a podocyták által termelt vascularis endothelialis növekedési faktor-C (VEGFC) kulcsfontosságú, hiányában (például praeeclampsia esetén a keringő szolúbilis VEGF-receptor-1 gátlóhatása miatt) endotheliosis, majd proteinuria alakulhat ki [11, 12]. Az endothelsejtek felszínét negatív töltésú glikoproteinek, glükózaminoglikánok borítják, melyek alapvetően a vascularis rheologiát és permeabilitást szabályozzák, de fontosak az immunsejt-adhézióban, valamint a komplementkomponensekkel, immunkomplexekkel történő interakciókban is. A glomerularis endothelsérülés egyik jellegzetes morfológiai indikátora az endokapilláris hipercellularitás mellett a GBM többrétegúvé válása, aminek hátterében sokszor transzplantációs glomerulonephropathia áll. Transzplantációt követően az endothelsejtekkel találkoznak először a recipiens monocytái és lymphocytái, melyek antigénként ismerik fel a donor endothelsejtjein kifejeződő humán leukocytaantigén-II (HLAII)-fehérjéket. Az ennek következtében indukálódó, donorspecifikus anti-HLAII-antitest-termeléssel járó humoralis immunválasz lokális immunkomplexek kialakulásához, endothelkárosodáshoz, végül pedig antitestmediált rejekcióhoz vezethet [13]. A haemolyticus uraemiás szindróma patológiai alapja a thromboticus microangiopathia, melynek során az aktiválódó koagulációs kaszkád által létrehozott fibrinlerakódások és thrombusok károsítják az endothelsejteket [14].

\section{Podocyták}

A podocyták a glomerularis kapilláris külső részét borítják, és a GBM-hez kapcsolódó lábnyúlványaik közötti, úgynevezett résdiafragma képezi a glomerularis filtrációs barrier utolsó elemét, mely a makromolekulák vizelettérbe történő kijutását hivatott gátolni. A glomerulust érő károsodás jellegzetes megnyilvánulása az, hogy a podocyták elveszítik lábnyúlványaikat, bennük apoptotikus folyamatok indukálódnak, és leválnak a GBM-ről. Ennek következtében a filtrációs barrier integritása sérül, és proteinuria alakul ki. A podocyták osztódóképessége elhanyagolható, de számos mitogén növekedési faktort képesek termelni - beleértve a VEGF-et, a TGF $\beta$ - $t$, valamint a CTGF-et -, melyekkel stimulálják a mesangialis sejtek proliferációját, extracellularismátrix-termelését [15]. A GBM-et érintő immunológiai eredetû károsítómechanizmusok a podocytákra is hatással vannak. A podocyták által expresszált megalin membránfehérje erősen immunogén, így az in situ létrejövő immunkomplexek szintén immunmediált gyulladásos folyamatokat válthatnak ki, ami membranosus glomerulonephritis kialakulásához vezet [16]. A minimális elváltozással járó nephro- 
sisszindróma szintén podocytasérüléssel jár együtt. A podocyták szerepet játszanak a természetes immunválasz mediálásában is, mivel a felszínükön kifejeződő Toll-szerü receptorok (például TLR4, TLR9) segítségével képesek felismerni a különböző patogéneket, melyek hatására gyulladásos citokineket expresszálnak [17].

\section{Parietalis epithelsejt}

A parietalis epithelsejtek alkotják a Bowman-tok belső felszínét borító egyrétegú laphámot, melynek sejtmagjai jellegzetesen betüremkednek a glomerulus vizelettere felé. Jelenleg nem ismert olyan glomerularis károsodással járó kórkép, mely specifikusan a parietalis epithelsejteket érintené, de glomerulussérülés során betöltött funkciójukat számos vizsgálati eredmény alátámasztja. Kimutatták, hogy gyulladásos folyamatok hatására proliferálnak, valamint képesek extracellularismátrix-komponensek termelésére [18]. Egyre több irodalmi adat támasztja alá, hogy a glomerularis sérülést követően fokozódó CTGF-, PDGFB-, valamint TGF $\beta$-termelésük révén a parietalis epithelsejtek kiemelt szerepet játszanak a fibrocellularis félhold kialakulásában több glomerularis károsodással járó betegség esetében (például fokális szegmentális glomerulosclerosis szindróma, gyorsan progrediáló glomerulonephritis, ANCA-asszociált vasculitis) [19].

\section{Az immunológiai tényezők szerepe}

\section{Immunkomplexek által kiváltott glomerulonephritis}

Az antigénból és a hozzá kapcsolódó immunglobulinokból, komplementfaktorokból álló immunkomplexek felelősek a glomerulonephritisek jelentős részéért. A vese glomerulusainak filtrációs tevékenysége és a kapillárisfal jelentôs negatív felületi töltése nagyban hozzájárul a keringő immunkomplexek filtrációs barrieren történő paszszív fennakadásához és felhalmozódásához (2/A ábra) [20]. Az immunkomplexek kialakulásáért felelős antigén lehet exogén, azaz külső forrásból származó, valamint endogén, tehát a szervezet saját molekulája. Exogén antigén okozta glomerulonephritisre példa a Streptococcusfertőzés során kialakuló akut glomerulonephritis, de állhat vírus (például hepatitis $\mathrm{B}$ ) vagy parazita (például Plasmodium spp.) is a betegség hátterében. Endogén antigének esetében az immunrendszer a szervezet saját molekulái ellen indít immunválaszt [21]. A szisztémás lupus erythematosus indukálta nephritis során a szervezet saját, kétszálú DNS-molekulái ellen indul humoralis immunválasz, és az így keletkező immunkomplexek a glomerulusban lerakódva patológiás folyamatokat indukálnak [22, 23]. Az immunkomplexek mérete az antitest/antigén aránytól függ. Ha az antitestek nagyobb mennyiségben vannak jelen, mint az antigén, akkor számos keresztkötést alakíthatnak ki az antigének között, növelve az immunkomplex méretét. A nagyméretű immunkomplexek fóleg a glomerulus subendothelialis, valamint mesangialis részén rakódnak le. Ezzel szemben ha az antigén nagyobb mennyiségben van jelen, mint az antitest, akkor az immunkomplexek mérete is kisebb lesz, melyek a glomerularis bazálmembrán területén képeznek a keringéstől, komplementfehérjéktől izolált, ezáltal kevésbé immunogén depozitumokat. Az immundepozitumok in situ is létrejöhetnek abban az esetben, ha az antitestek által felismert antigén valamelyik glomerularis struktúrához asszociáltan fejeződik ki (2/B ábra). Jó példa az in situ immunkomplexek kialakulására a glomerularis bazálmembrán IV-es kollagénjének $\alpha 3$-láncára specifikus antitestek által indukált antiglomerularis bazálmembrán nephritis. Goodpasture-szindróma esetén ezen autoantitestek keresztreakciót adnak a tüdő alveolaris sejtek bazálmembrán-fehérjéivel, ahol szintén gyulladásos folyamatokat indukálnak, valamint a kórképet szisztémás vasculitis is kísérheti [24]. Mind a keringésből származó, mind pedig az in situ képződő immunkomplexek lokális gyulladás kialakulásához vezetnek a glomerulusban. A folyamat hátterében az immunkomplexek által kiváltott leukocytainfiltráció és -aktiváció, fokozott gyulladásoscitokin- és növekedésifaktor-termelés, valamint a komplement- és koagulációsfaktor-aktiváció áll. Szintén immunkomplexek lerakódása felelős a fibrinoid necrosisért, melynek során a kapilláris-endothelsejteken

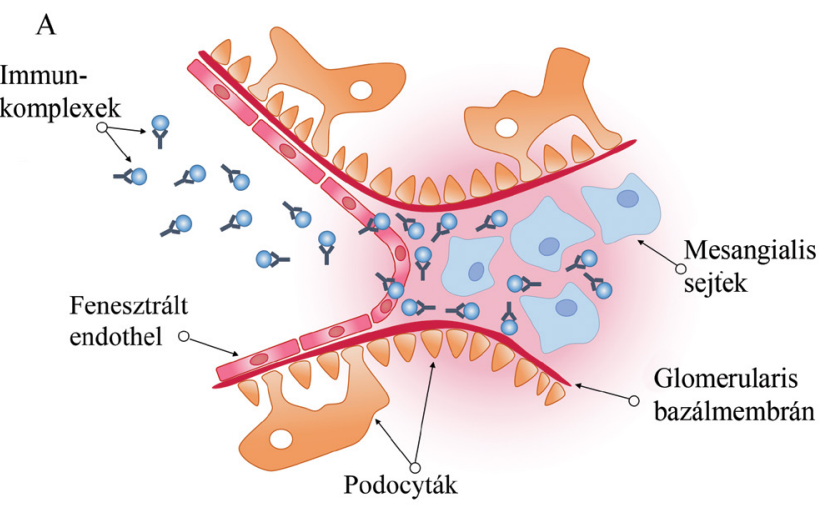

B

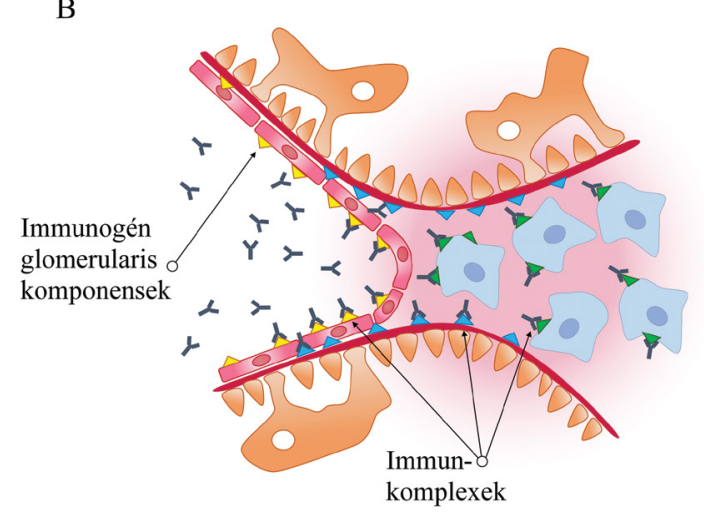

\begin{tabular}{l|l} 
2. ábra & Keringő és in situ immunkomplexek kialakulása a glomerulus
\end{tabular} ban (Couser nyomán) [21] 
lerakódó, fibrintartalmú immunkomplexek necrosist indukálnak [25]. A komplementrendszer komplementkaszkádjának immunglobulin-függő aktiválódása szintén szerepet játszik a glomerulussejtek károsodásaiban [26].

\section{Sejtes immunválasz}

Az immunrendszer sejtes elemei (lymphocyták, granulocyták, monocyták, macrophagok) számos módon részt vehetnek az immunmediált glomerularis betegségek patomechanizmusában. Az immunsejtek szerepe a glomerulonephritisekben kettős, mivel indukálhatják, de akár gátolhatják is a glomeruluskárosodást. Alapvető szerepük van a lokális gyulladásos folyamatok kiváltásában, de a károsodást követően részt vesznek a szöveti regenerációban és a glomerulus homeostasisának visszaállításában is. Multifoton-mikroszkópos technikával igazolták, hogy fiziológiás körülmények között a monocyták és a neutrophil granulocyták „járőröznek” a glomeruluson belül [27]. Ezen rezidens immunsejteknek fontos szerepük van a természetes immunválasz iniciálásában, melynek központi eleme a különböző leukocytapopulációknak a kemotaktikus citokinek és adhéziós molekulák segítségével történő lokális „toborzása”. Az adhéziós molekulák (például CD11b/CD18, P-szelektin) segítik a keringő leukocytáknak a kapilláris-endothelsejteken történó megtapadását és átjutását. A leukocytainfiltrációnak szintén fontos faktorai a kemoattraktáns citokinek (például CXCL8/IL8) és a komplementrendszer komponensei (C3a, C5a), melyek kemotaxist indukálva a sérülés helyszínére vonzzák az immunsejteket [28].

\section{B-lymphocyták}

A B-lymphocyták, valamint a belőlük differenciálódott antitesttermelő plazmasejtek képezik a humoralis immunválasz alapját. A sejtmembránjukban jelen lévő immunglobulin-molekula, az úgynevezett B-lymphocyta-receptor ismeri fel a specificitásának megfelelő antigénmintázatot. Képesek a felismert antigének fagocitálására, feldolgozására, majd fó hisztokompatibilitási komplex-II (MHCII-) molekuláikon keresztüli prezentálására a T-lymphocyták számára [29]. A B- és T-lymphocyták közötti kölcsönhatás kialakulásához és sejtaktivációs folyamatok elindításához elengedhetetlen a két sejttípus által kifejezett kostimulátor molekulák közötti (például CD40/CD40L, B7/CD28) szoros kapcsolat. A B- és T-lymphocyták közötti interakciót lokálisan magas citokinkoncentráció jellemzi, mely biztosítja, hogy elsősorban az antigént bemutató B-lymphocyták szaporodjanak és differenciálódjanak az aktivált T-lymphocyták által termelt citokinek hatására [30]. Az aktivációs folyamat eredményeként a B-lymphocyták elveszítik membránkötött immunglobulinjaikat, és ellenanyag-termelő plazmasejtté érnek. A plazmasejtek által termelt ellenanyagok epitópjaikhoz kötődve keringő, valamint in situ immunkomplexeket hozhatnak létre a glomeru- lusban. Az autoimmun glomerularis betegségekben (antiglomerularis bazálmembrán nephritis, lupus nephritis) a szervezet saját fehérjéit felismerő autoreaktív B-lymphocyták és az általuk termelt autoantitestek felelősek a glomeruluskárosodásért.

\section{T-lymphocyták}

A T-lymphocyták ellenanyag-termelésre nem képesek, de a B-lymphocytákhoz hasonlóan membránjukban immunglobulin-szerű antigénfelismerő receptorok lokalizálódnak. Elsősorban az antigénprezentáló sejtek (B-lymphocyták, macrophagok, dendritikus sejtek) által MHCII-molekulán keresztül bemutatott fehérjetermészetû antigéneket ismernek fel. A T-lymphocyták különböző effektori funkcióik alapján alpopulációkra oszthatók. Két legjobban karakterizált csoportjukat a CD4+ segítő (Th-), valamint a CD8 + citotoxikus (Tc-) sejtek alkotják. Emellett az immunválasz szabályozásában fontos szerepet játszanak a gyulladásos Th17-, valamint a gyulladáscsökkentő regulátor T-sejtek (Treg) [31]. Citokintermelésük alapján a Th-sejtek két további alpopulációba sorolhatók. A Thl-sejtek a macrophagokat aktiváló, gyulladásos és a citotoxikus folyamatokban szerepet játszó IL2-t, IFN $\gamma$-t, valamint TNF $\alpha$-t termelnek. A Th2sejtek pedig IL4-, IL5-, IL6- és IL10-termelésük révén elsősorban a B-lymphocyták aktiválásában és ellenanyagtermelő plazmasejtté érésében játszanak szerepet. A Th1- és Th2-sejt-polarizáció irányát a citokinkörnyezet, az antigénprezentáló sejtekkel kialakított kapcsolat erőssége, valamint az immunválaszt indukáló antigén menynyisége határozza meg [32]. A mérsékeltebb immunfolyamatok inkább a humoralis immunválasz kialakítását segítő Th2-sejtek differenciálódásának kedveznek, míg az akut, nagyfokú immunstimulációval járó folyamatok a jellemzően a sejtes immunválaszt indukáló Thl-sejtek kialakulását segítik elő. A Thl-sejtek dominanciája jellemző a proliferatív glomerulonephritisre, míg a Th2sejtek a humoralis immunválasz indukálásán keresztül a membranosus glomerulonephritis kialakulásában játszanak szerepet. A Th17-sejtek az IL17 gyulladásos citokin termelése révén jelentősen hozzájárulnak a glomerularis károsodások progressziójához mind a patogén indukálta, mind pedig az autoimmun eredetû́ nephritisekben [33]. A különböző alpopulációkba tartozó T-lymphocyták elengedhetetlenek a patogének elleni küzdelemben, de ezzel párhuzamosan központi szerepet játszanak szinte valamennyi, gyulladással és autoimmun folyamattal együtt járó glomerularis károsodásban [34].

\section{Neutrophil granulocyták}

A neutrophil granulocyták az akut gyulladásos folyamatok megindításának kulcsszereplői. Szintén fontos funkciójuk az elhalt vagy tumorossá vált sejtek, illetve az opszonizált mikrobák fagocitálása. Aktivációs stimulus (sérülés, patogén felismerése) esetén degranulálódnak, és a 
granulumaikból lizoszomális enzimek (kollagenáz, lizozim, mieloperoxidáz), valamint reaktívoxigén-gyökök szabadulnak fel. Ezen enzimek és faktorok segítik az antimikrobiális védekezést, de ezzel együtt glomeruluskárosító hatással is bírnak, mivel roncsolják a kapillárisendothelsejteket, fokozzák a filtrációs barrier permeabilitását és az extracellularismátrix-komponensek lebontását, valamint aktiválják a koagulációs kaszkádot. ANCA-aszszociált vasculitis esetén autoantitestek képződnek a neutrophil granulocyták által termelt mieloperoxidáz enzim ellen [35]. Az autoantitestek fokozzák a neutrophilaktivációt $\mathrm{Fc} \gamma$-receptoraikon keresztül, mely folyamat gyorsan progrediáló, immundepozitumok nélküli ( „pauci immun”), félholdképződéssel járó glomerulonephritishez vezet. A közelmúltban írták le azt a jelenséget, hogy a neutrophilek hálószerű DNS-ből és kromatinfehérjékből álló, úgynevezett „neutrophil extracellularis csapdát" bocsátanak ki apoptózisuk során, mely struktúra 10-15-ször nagyobb helyet foglal el, mint az eredeti sejt, és hozzájárul a patogének elleni védekezéshez, valamint a koagulációs kaszkád elindításához [36].

\section{Monocyták/Macrophagok}

A monocyták haemopoesisüket követően a véráramba kerülnek, ahonnan kemotaktikus citokinek (például MCP1, CCL5) hatására kilépnek, és a különböző szövetekben macrophagokká differenciálódnak [37]. A keringésben maradó monocyták sejtadhéziós és kemokinreceptoraik érzékenységét tekintve eltérőek a szövetekbe vándorlóktól, érésük során pedig úgynevezett endothelialis macrophagokká differenciálódnak. A macrophagok elsődleges feladata a kórokozók felismerése - mintázatfelismerő Toll-szerű receptoraik segítségével -, azok bekebelezése és eliminálása, ezt követően pedig MHCIImolekulákon keresztül a T-lymphocytáknak történő bemutatása [38]. A szöveti macrophagokat M1- és M2altípusra lehet felosztani. Az IFN $\gamma$ hatására kialakuló Ml-macrophagok felelősek a gyulladásos és citotoxikus folyamatok indukálásáért, a reaktívoxigén-gyökök termeléséért, a szövetkárosításért és az antimikrobiális válaszért. Az IL4 és az IL13 hatására differenciálódó M2macrophagok a sejtes törmelék eltakarításában, az angiogenesisben, a szöveti regenerációban és átépülésben, továbbá a gyulladásos válasz csökkentésében játszanak szerepet [39] (3. ábra). Számos glomerularis betegségben kimutatták a jelenlétüket (például IgA-nephropathia, antiglomerularis bazálmembrán nephritis), továbbá infiltrációjuk mértéke korrelál a kialakult gyulladással [40].

\section{Komplementrendszer}

A komplementrendszer a vérben és a különböző testnedvekben inaktív állapotban jelen lévő, egymást kaszkádszerúen aktiváló faktorok, a folyamatot szabályozó molekulák, valamint az egyes aktiválódott komponenseket megkötő receptorok összessége. Elemei alapvetően a májban képződnek, de a különböző szöveti sérülések lokálisan is indukálhatják termelődésüket. A patogének-

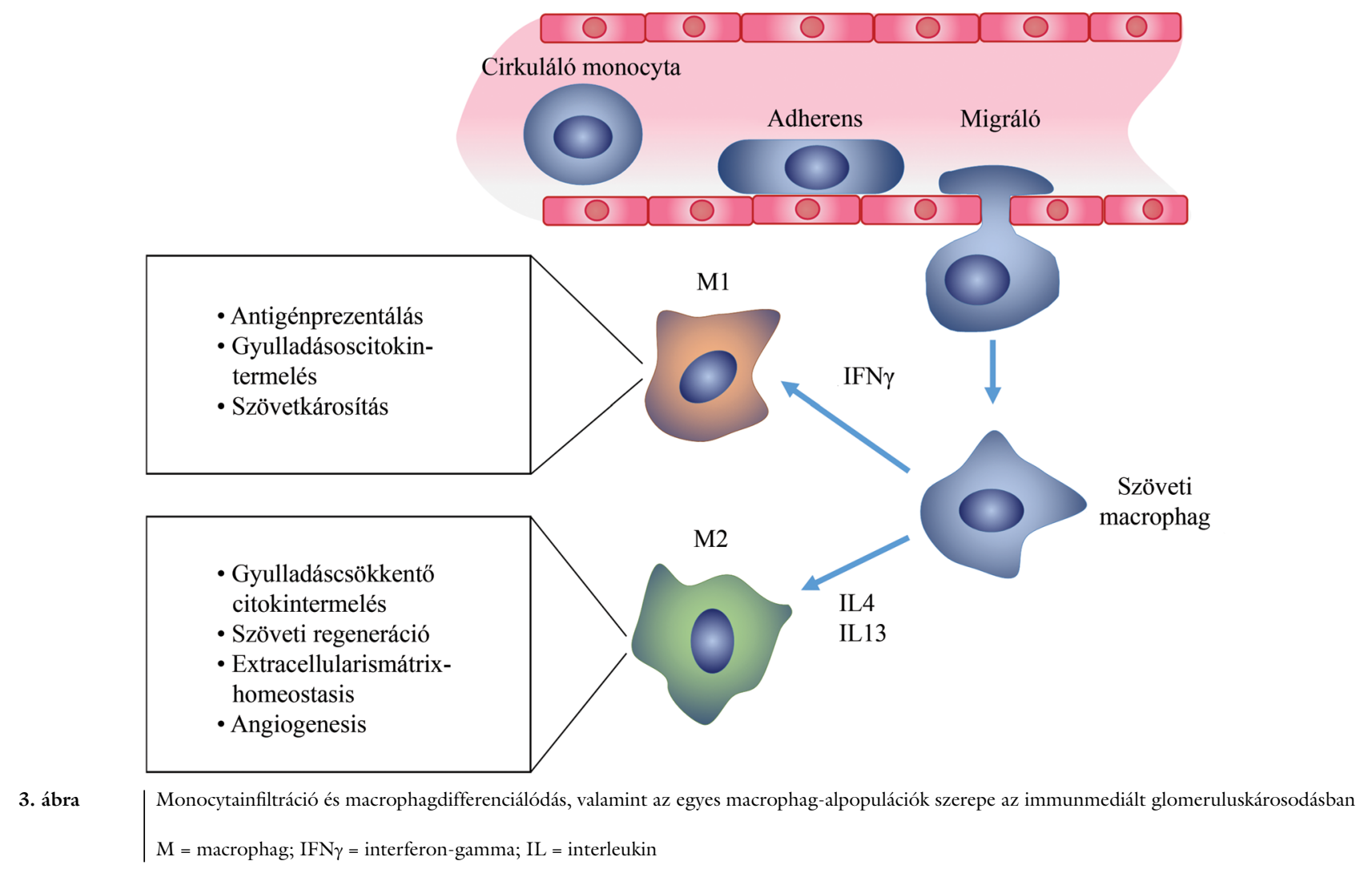




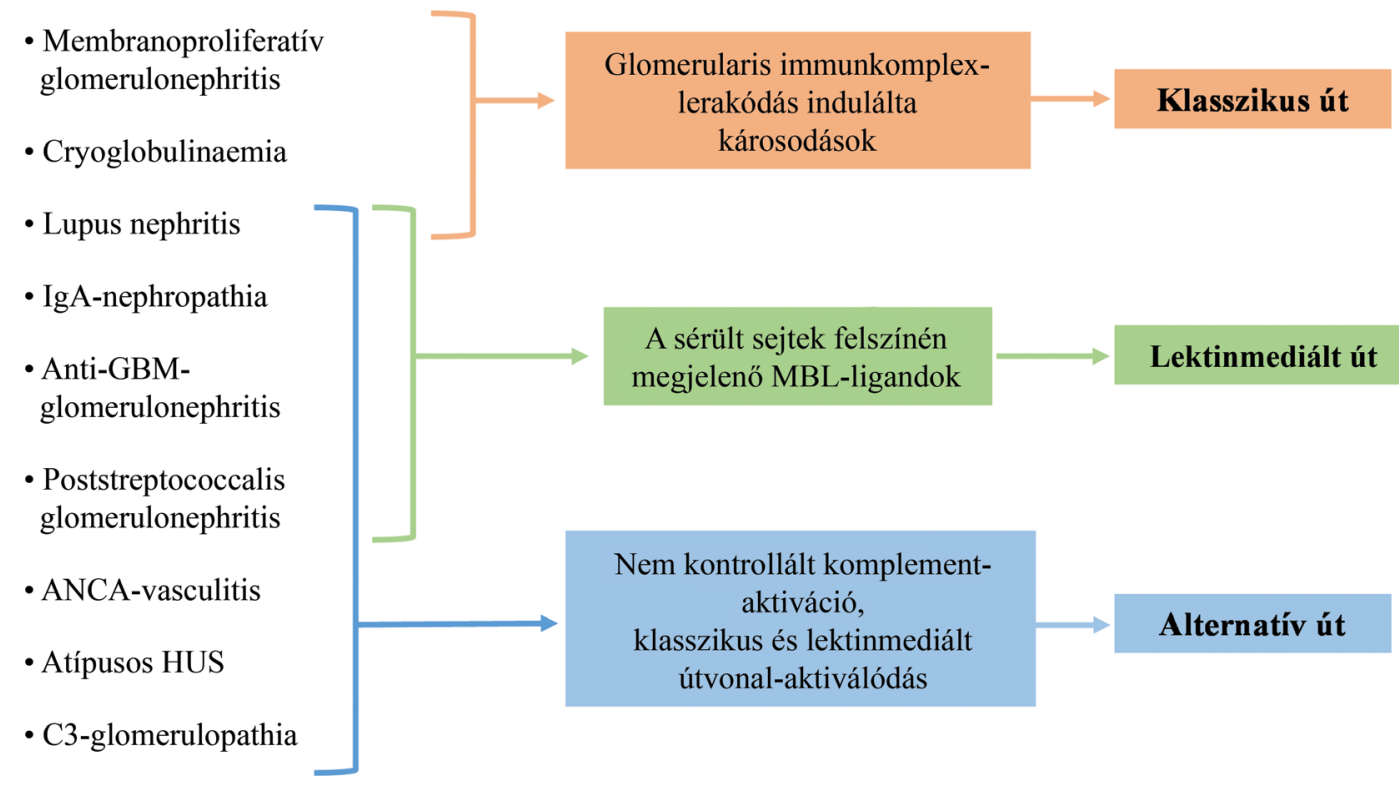

4. ábra A különböző glomerularis betegségek és a komplementrendszer kapcsolata ( Thurman és mtsa nyomán) [41]
ANCA = a neutrophil granulocyták citoplazmájában lévő különféle enzimek elleni antitestek gyújtőneve; anti-GBM = antiglomerularis bazálmembrán;
HUS = haemolyticus uraemiás szindróma; IgA = immunglobulin-A; MBL = mannózkötő lektin

hez, elpusztult sejtekhez kötődő komplementkomponensek segítik azok felismerését és eliminálását az immunsejtek számára (opszonizáció) [41] (4. ábra). A komplementrendszer központi elemeinek nómenklatúrája komplement (C)1-től C9-ig terjed, aktiválódása pedig három útvonalon, a klasszikus, az alternatív, valamint a lektinfüggó úton indulhat el. A klasszikus útvonalat IgG- és IgM-tartalmú immunkomplexek és a hozzájuk kötődő Clq-komplementfragmensek indítják el. Az útvonal aktiválódása lokális immunsejt-infiltrációhoz és gyulladásos folyamatok iniciálódásához vezet. A klasszikus útvonal aktivációja a C3- és C4-komplementkomponensek glomerularis lerakódásával jár, ami kimutatható számos glomerularis betegségben (például membranoproliferativ glomerulonephritis, lupus nephritis, cryoglobulinaemia asszociálta glomerulonephritis, anti-GBMglomerulonephritis). Az alternativ útvonalat a C3komplementfehérje spontán módon bekövetkező hasítása során képződő C3b-fragmensek indítják el. Amennyiben a C3b további, komplementkaszkád-aktiváló képessége nem megfelelően gátolt, az szövetkárosodással járó folyamatokhoz vezet. A komplementrendszer alternatív úton történő aktiválásának következtében számos olyan komplementfragmens szabadul fel, mely a komplementkaszkád klasszikus útvonalát is elindítja. Az alternatív útvonal kóros aktivitása az egyik legjelentősebb rizikófaktora az atípusos haemolyticus uraemiás szindrómának (aHUS), de szerepet játszik más, a klasszikus útvonal aktivációja következtében kialakuló glomerulonephritisben is [42]. A lektinfüggö útvonalat a szénhidrát-molekulákhoz kötődő, a szérumban szabadon keringő MBL- (mannose-binding lectin) molekulák és a hozzájuk asszociált MASP- (MBL-associated serine protease) proteázok indítják el. Az MBL által felismert szénhidrátmotívumok megtalálhatók a baktériumok sejtfelszínén, de apoptotizáló, nekrotizáló sejtek felszínén is kifejeződnek. Az MBL-MASP komplex által elindított komplementaktiváció lépései közel hasonlóak, mint a klasszikus útvonal esetében. A lektinfüggő útvonal aktiválódhat IgA-nephropathiában, lupus nephritisben, valamint poststreptococcalis glomerulonephritisben [43]. Bár három különböző útvonalon indulhat el a komplementkaszkád, számos közös elem található bennük. Ilyen elem a klasszikus és a lektinmediált út közös C3konvertáza, a C4b2b. A C3-komponens hasítása eredményeként keletkező C3b-fragmentum a C3-konvertáz mellé kötődve létrehozza a klasszikus út C5-konvertáz enzimét (C4b2bC3b) [44]. A C5-molekula hasításával a komplementrendszer további aktiválódása azonos útra terelődik, függetlenül a kiindulási stimulustól. A C5molekula hasításakor keletkező C5b, valamint a C6-, C7-, C8-, C9-polimerizátum létrehozza a C5b-9-cel is jelzett membránkárosító komplexet (MAC), amely belesüllyedve a célsejtek membránjába, pórust alakít ki, ami a sejt pusztulásához vezet [45].

\section{Következtetés}

A krónikus vesebetegségek incidenciája folyamatosan növekszik, ezért fontos, hogy megértsük a betegség mögött meghúzódó kóroki folyamatokat. A krónikus vesebetegség kialakulásának egyik leggyakoribb oka a glome- 
rulusok immunmediált károsodása. Ennek hátterében az áll, hogy a glomerulusok filtrációs tevékenysége jelentősen fokozza kitettségüket a szervezeten belül zajló immunreakcióknak. A glomerulusok immunogén fehérjekomponensei, valamint a kapilláris-endothelsejtek, a glomerularis bazálmembrán és a podocyták által létrehozott filtrációs barrier nagyban hozzájárul az immunkomplexek lokális felhalmozódásához, aminek talaján az immunrendszer sejtes és humoralis elemei aktiválódnak, és lokális gyulladással járó patológiás folyamatokat indukálnak. Az immunmediált glomerularis károsodás hatására a glomerulusban apoptózissal, szöveti átrendeződéssel járó mechanizmusok indulnak be, melyek hatására a glomerulusok szûrletképző funkciója csökken, ezért a vesefunkció beszúkül. Ha megismerjük a glomerularis károsodások mögött álló immunmediált folyamatok patomechanizmusát, az lehetőséget teremt új diagnosztikus markerek azonosítására, valamint hatékony terápiás eljárások kifejlesztésére.

Anyagi támogatás: A közlemény megírása az OTKA Kl16928., K125470,, a 20382-3/2018 FEKUTSTRAT; a Semmelweis Tudományos és Innovációs Alap, valamint a Bolyai János Kutatási Ösztöndíj támogatásával valósult meg.

Szerzői munkamegosztás: P. D.: Átfogó irodalomkutatás a témához kapcsolódóan, a közlemény megírása. V. Á.: Szakmai, mentori támogatás, a kézirat szerkesztése. Sz. A. J.: Szakértői feladatok ellátása, a kézirat véleményezése. A cikk végleges változatát valamennyi szerző elolvasta és jóváhagyta.

Érdekeltségek: A szerzőknek nincsenek érdekeltségeik.

\section{Köszönetnyilvánítás}

Köszönettel tartozunk Dr. Tulassay Tivadar professzor únak értékes szakmai tanácsaiért.

\section{Irodalom}

[1] Jha V, Garcia-Garcia G, Iseki K, et al. Chronic kidney disease: global dimension and perspectives. Lancet 2013; 382: 260-272. [Correction: Lancet 2013; 382: 208.]

[2] Woroniecki RP, Schnaper HW. Progression of glomerular and tubular disease in pediatrics. Semin Nephrol. 2009; 29: 412 424 .

[3] Kitching AR, Hutton HL. The players: cells involved in glomerular disease. Clin J Am Soc Nephrol. 2016; 11: 1664-1674.

[4] Nagata M. Immune-mediated glomerular injury. In: Avner E, Harmon W, Niaudet P, et al. (eds.) Pediatric nephrology. Springer, Berlin, Heidelberg, 2009; pp. 703-742.

[5] Su H, Lei CT, Zhang C. Interleukin-6 signaling pathway and its role in kidney disease: an update. Front Immunol. 2017; 8: 405.

[6] Nadasdy T, Laszik Z, Blick KE, et al. Proliferative activity of intrinsic cell populations in the normal human kidney. J Am Soc Nephrol. 1994; 4: 2032-2039.
[7] Steffes MW, Østerby R, Chavers B, et al. Mesangial expansion as a central mechanism for loss of kidney function in diabetic patients. Diabetes 1989; 38: 1077-1081.

[8] Miner JH. The glomerular basement membrane. Exp Cell Res. 2012; 318: 973-978.

[9] McAdoo SP, Pusey CD. Anti-glomerular basement membrane disease. Clin J Am Soc Nephrol. 2017; 12: 1162-1172.

[10] Weening JJ, D'Agati VD, Schwartz MM, et al. The classification of glomerulonephritis in systemic lupus erythematosus revisited. J Am Soc Nephrol. 2004; 15: 241-250. [Correction: J Am Soc Nephrol. 2004; 15: 835-836.]

[11] Fan X, Rai A, Kambham N, et al. Endometrial VEGF induces placental sFLT1 and leads to pregnancy complications. J Clin Invest. 2014; 124: 4941-4952.

[12] Müller-Deile J, Schiffer M. Renal involvement in preeclampsia: similarities to VEGF ablation therapy. J Pregnancy 2011; 2011: 176973.

[13] Montgomery RA, Tatapudi VS, Leffell MS, et al. HLA in transplantation. Nat Rev Nephrol. 2018; 14: 558-570.

[14] Ruggenenti P, Noris M, Remuzzi G. Thrombotic microangiopathy, hemolytic uremic syndrome, and thrombotic thrombocytopenic purpura. Kidney Int. 2001; 60: 831-846.

[15] Lee HS. Paracrine role for TGF- $\beta$-induced CTGF and VEGF in mesangial matrix expansion in progressive glomerular disease. Histol Histopathol. 2012; 27: 1131-1141.

[16] Farquhar MG, Saito A, Kerjaschki D, et al. The Heymann nephritis antigenic complex: megalin (gp330) and RAP. J Am Soc Nephrol. 1995; 6: 35-47.

[17] Xia H, Bao W, Shi S. Innate immune activity in glomerular podocytes. Front Immunol. 2017; 8: 122.

[18] Shankland SJ, Smeets B, Pippin JW, et al. The emergence of the glomerular parietal epithelial cell. Nat Rev Nephrol. 2014; 10: 158-173.

[19] Ohse T, Pippin JW, Chang AM, et al. The enigmatic parietal epithelial cell is finally getting noticed: a review. Kidney Int. 2009; 76: 1225-1238.

[20] Kurts C, Panzer U, Anders H-J, et al. The immune system and kidney disease: basic concepts and clinical implications. Nat Rev Immunol. 2013; 13: 738-753.

[21] Couser WG. Basic and translational concepts of immune-mediated glomerular diseases. J Am Soc Nephrol. 2012; 23: 381-399.

[22] Borchers AT, Leibushor N, Naguwa SM, et al. Lupus nephritis: a critical review. Autoimmun Rev. 2012; 12: 174-194.

[23] Giannakakis K, Faraggiana T. Histopathology of lupus nephritis. Clin Rev Allergy Immunol. 2011; 40: 170-180.

[24] McAdoo SP, Pusey CD. Anti-glomerular basement membrane disease. Clin J Am Soc Nephrol. 2017; 12: 1162-1172.

[25] Yoshida M, Sasaki M, Sugisaki K, et al. Neutrophil extracellular trap components in fibrinoid necrosis of the kidney with myeloperoxidase-ANCA-associated vasculitis. Clin Kidney J. 2013; 6: 308-312.

[26] Nangaku M, Couser WG. Mechanisms of immune-deposit formation and the mediation of immune renal injury. Clin Exp Nephrol. 2005; 9: 183-191.

[27] Devi S, Li A, Westhorpe CL, et al. Multiphoton imaging reveals a new leukocyte recruitment paradigm in the glomerulus. Nat Med. 2013; 19: 107-112. [Correction: Nat Med. 2016; 22: 446.]

[28] Kuligowski MP, Kitching AR, Hickey MJ. Leukocyte recruitment to the inflamed glomerulus: a critical role for platelet-derived P-selectin in the absence of rolling. J Immunol. 2006; 176: 6991-6999.

[29] Bromley SK, Burack WR, Johnson KG, et al. The immunological synapse. Annu Rev Immunol. 2001; 19: 375-396.

[30] Leibler C, Thiolat A, Elsner RA, et al. Costimulatory blockade molecules and B-cell-mediated immune response: current knowledge and perspectives. Kidney Int. 2019; 95: 774-786. 
[31] Golubovskaya V, Wu L. Different subsets of T cells, memory, effector functions, and CAR-T immunotherapy. Cancers (Basel) 2016; 8: 36.

[32] Kaiko GE, Horvat JC, Beagley KW, et al. Immunological decision-making: how does the immune system decide to mount a helper T-cell response? Immunology 2008; 123: 326-338.

[33] Krebs CF, Schmidt T, Riedel JH, et al. T helper type 17 cells in immune-mediated glomerular disease. Nat Rev Nephrol. 2017; 13: 647-659.

[34] Wu J, Hicks J, Borillo J, et al. CD4 ${ }^{+} \mathrm{T}$ cells specific to a glomerular basement membrane antigen mediate glomerulonephritis. J Clin Invest. 2002; 109: 517-524.

[35] Jennette JC, Nachman PH. ANCA glomerulonephritis and vasculitis. Clin J Am Soc Nephrol. 2017; 12: 1680-1691.

[36] Kessenbrock K, Krumbholz M, Schönermarck U, et al. Netting neutrophils in autoimmune small-vessel vasculitis. Nat Med. 2009 ; 15: 623-625

[37] Chung AC, Lan HY. Chemokines in renal injury. J Am Soc Nephrol. 2011; 22: 802-809.

[38] Smith KD. Toll-like receptors in kidney disease. Curr Opin Nephrol Hypertens. 2009; 18: 189.

[39] Han HI, Skvarca LB, Espiritu EB, et al. The role of macrophages during acute kidney injury: destruction and repair. Pediatr Nephrol. 2019; 34: 561-569.
[40] Tang PM, Nikolic-Paterson DJ, Lan HY. Macrophages: versatile players in renal inflammation and fibrosis. Nat Rev Nephrol. 2019; 15: 144-158.

[41] Thurman JM, Nester CM. All things complement. Clin J Am Soc Nephrol. 2016; 11: 1856-1866.

[42] Noris M, Remuzzi G. Atypical hemolytic-uremic syndrome. N Engl J Med. 2009; 361: 1676-1687.

[43] Thurman JM. Many drugs for many targets: novel treatments for complement-mediated glomerular disease. Nephrol Dial Transplant. 2017; 32 (Suppl 1): i57-i64.

[44] Erdei A, Sándor N, Mácsik-Valent B, et al. The versatile functions of complement C3-derived ligands. Immunol Rev. 2016; 274: 127-140.

[45] Janeway CA Jr, Travers P, Walport M, et al. The complement system and innate immunity. In: Janeway CA Jr, Travers P, Walport $\mathrm{M}$, et al. Immunobiology: the immune system in health and disease. 5th edition. Garland Science, New York, NY, 2001; pp.

(Pap Domonkos dr., Budapest, Bókay J. u. 54., 1083 e-mail: pap.domonkos@med.semmelweis-univ.hu)

\section{"Medicina calamitatis est aequanimitas." (A baj orvossága a rendíthetetlenség.)}

A cikk a Creative Commons Attribution 4.0 International License (https://creativecommons.org/licenses/by/4.0/) feltételei szerint publikált Open Access közlemény, melynek szellemében a cikk bármilyen médiumban szabadon felhasználható, megosztható és újraközölhető, feltéve, hogy az eredeti szerzỏ és a közlés helye, illetve a CC License linkje és az esetlegesen végrehajtott módosítások feltüntetésre kerülnek. (SID_1) 